\title{
MEASUREMENT OF THE SURFACE FORCES IN SOILS
}

\author{
A DISSERTATION \\ SUBMITTED TO THE FACULTY OF THE OGDEN GRADUATE SCHOOL \\ OF SCIENCE IN CANDIDACY FOR THE DEGREE \\ OF DOCTOR OF PHILOSOPHY \\ (DEPARTMENT OF BOTANY)
}

BY

CHARLES ALBERT SHULL

$\vdots \vdots$

A Private Edition

Distributed By

The University of Chicago Libraries

Reprinted from

The Botanical Gazette, Vol. LXII, No. I

Chicago, 19ı6 



\title{
MEASUREMENT OF THE SURFACE FORCES IN SOILS
}

\author{
A DISSERTATION \\ SUBMITTED TO THE FACULTY OF THE OGDEN GRADUATE SCHOOL \\ OF SCIENCE IN CANDIDACY FOR THE DEGREE \\ OF DOCTOR OF PHILOSOPHY \\ (DEPARTMENT OF BOTANY)
}

BY

CHARLES ALBERT SHULL

A Private Edition

Distributed By

The University of Chicago Libraries

Reprinted from

The Botanical Gazetre, Vol. LXII, No. I

Chicago, 19r6 



\title{
T H E
}

\section{Botanical Gazette JULY 1916}

\author{
MEASUREMENT OF THE SURFACE FORCES IN SOILS \\ CONTRIBUTIONS FROM THE HULL BOTANICAL LABORATORY 2 I7 \\ ChARLES A L B ERT SHUL \\ (WITH FIVE FIGURES)
}

\section{Introduction}

Many investigations of soil moisture have been made, especially during recent years, in attempts to learn something of its mechanics and its relations to plant growth. In a general way the dominating importance of the soil water to plants has long been recognized; but notwithstanding the large amount of work done up to the present time, we still lack some of the most fundamental, elementary facts regarding the physico-chemical relations of the water and soil. This is true generally of that region of soil moisture which lies between what is called the wilting coefficient of the soil and air-dry soil, and more particularly of that critical region immediately below the wilting coefficient.

The discovery of semipermeable coats in seeds in recent years by Brown (4), SchröDER (30), and others has made it possible to measure approximately the force with which the colloidal gels of the seed attract water. In a former paper (33) it was shown that by means of osmotic solutions whose forces are known the imbibition force of a seed at any given moisture content from saturation to air-dry could be determined approximately.

Because of the rapid establishment of moisture equilibrium relations after disturbance in Xanthium seeds, this seed has been 
chosen for a further investigation of the moisture relations of seeds, with special reference to the moisture held by soil particles. The main purpose of the work was to find some means of measuring the force with which particles of soils of varying fineness retain moisture at different degrees of dryness, and to obtain some more definite knowledge concerning the amount of "back pull" occurring in soils when the total moisture content is so low as to be unavailable to growing plants. Special interest centered in the conditions obtaining in the critical region at and just below the wilting coefficient.

This paper presents the principal results obtained during the last three years. Since the osmotic method of measuring the internal forces of seeds is obviously restricted in practice to such seeds as have a perfectly semipermeable coat, a new method was attempted, based upon a determination of the vapor pressure equilibrium between seeds and osmotic solutions of varying strengths. This method has the advantage of being applicable to all sorts of seeds, regardless of the kind of testa present; but since von SCHRÖDER (3I) and BANCROFT (2) have shown that colloids may not have the same moisture relations to gaseous moisture that they have to water itself, the values obtained by the vapor pressure method have not been used as the basis of comparison with soils in this work. The values for the internal force of seeds as determined by osmotic solutions of various strengths will therefore be used as a basis for comparing the moisture-holding power of fine soil particles.

A number of soils have been used in the investigations, and it is believed that the methods of measurement used here will prove valuable in many kinds of soil moisture studies, since the determinations, while giving excellent data as to the physical relations of the soil moisture, yield at the same time results of considerable physiological significance. The results are more valuable, therefore, than purely physical determinations, because they can be interpreted in terms of plant activity. For, after all, it is the plant in relation to its environment, not merely the environment, that we need to understand.

The work has been carried on in the Plant Physiological Laboratory of the University of Kansas, and in the Hull Botanical 
Laboratory of the University of Chicago, where all needed facilities have been generously provided.

\section{Historical}

The general status of our knowledge of the forces operative in soils was briefly discussed by CAMERON (Io) several years ago. It is obvious from this account that up to the present time we have known very little about soil forces within the range of unavailable moisture, that is, between the wilting coefficient and air-dry condition of the soil.

The attempts thus far made at measurement of the surface forces which are known to exist in finely divided matter of all kinds have been made from various angles, but they can be classed under two main heads: (a) physical, and (b) physiological.

\section{PHYSICAL MEASUREMENTS}

A. Heat of wetting Method.-The principle of heat of wetting was discovered by Pouillet (26) a good many years ago. He found that all kinds of dry powders, from inorganic substances and porous organic matter, yielded heat on being wet with fluids like water, oil, alcohol, etc. The organic substances yielded the greater amount of heat because, he stated, the organic matter was composed of particles incomparably thinner than the finest inorganic powders.

The literature dealing with the application of this principle to measurements of surface force has been reviewed so recently by Patten (25) that it will not be necessary to go into the details of it here. It will be sufficient to point out that through the work of Rose (28) and Jungk (r9) we gained the conception that water is condensed on the surface of the powdered inorganic or finely divided organic substances, and that the release of heat is due to this compression. The quantitative studies of NäGELI (23) made it possible for SACHS (29) to calculate the surface forces in starch grains. Since Joule had shown that 34.3 atmospheres of pressure raises the temperature of water $0.03^{\circ} \mathrm{C}$., the amount of heat produced by starch on being wet would indicate much more than $10, \infty 00$ atmospheres of surface force compression. SAcHS assumed, of course, NÄGELI's theory of the structure of organic matter. 
The physicists Young, Duprë, and Lord Rayleigh have estimated the surface forces of finely divided absolutely dry matter at from II,000 to 25,000 atmospheres. LAGERGREN'S (20) estimate for charcoal fine enough to have $4 \mathrm{sq}$. $\mathrm{m}$. of internal surface per gram was 6150 atmospheres.

It is probable that this method would give results too high for soils, for, as MÜNTZ and GAUDECHON (22) have shown, there are other sources of heat release than mere compression when absolutely dry soil and water are mixed. Heat of solution, dilution, and hydration may make considerable errors in estimates of surface forces by this means. The statement frequently made that the force of surface condensation in soils runs from 6,000 to 25,000 atmospheres, as by Cameron (Io), and by Brown and Smith (5), is based upon the discussion previously mentioned.

B. Compression method.-Rodewald (27) has used a different method in measuring the forces on the surface of starch particles, which has the advantage of being a direct method; that is, the forces of compression are measured by the amount of compression produced instead of by the amount of heat produced. He found that I gm. of oven-dry starch absorbed $0.326 \mathrm{gm}$. of water in becoming saturated. But while the starch swelled, the swelling did not amount to as much as the volume of water absorbed. In other words, there was a volume loss due to compression of the water. The amount of volume loss was $0.0432 \mathrm{cc}$, and if we refer this to a gram of water, the volume loss is equal to $0.1325 \mathrm{cc}$. per gm. The compression coefficient of water is calculated by WÜLLNER to be $0.00004659 \mathrm{cc}$. per $\mathrm{gm}$. for each atmosphere of pressure exerted. This would give a pressure of 282I atmospheres for the compression actually obtained if we refer the compression solely to the water involved.

By a slightly different method of calculating the force of compression RODEWALD obtained a result of 2523 atmospheres, which is not referred to the water alone, but to the whole system of starch and water. He thinks that the close agreement shows that water alone is involved, or that starch happens to have about the same coefficient of compressibility as water.

The low value obtained by RODEWALD as compared with the values for inorganic bodies, PAtTen thinks is due to the fact that 
imbibition and absorption are both involved in the starch, and that a much lower value must be obtained than where absorption alone occurs. On the other hand, it will give a higher value than where imbibition alone occurs.

While these determinations of the surface force in absolutely dry matter are interesting, they have no practical value, for such forces as these do not occur in ordinary soils containing capillary moisture, or even in air-dry soils and seeds, for it is evident that the air-dry soil or seed already holds as hygroscopic moisture the water that it would absorb with such remarkable energy if the particles were absolutely dry. However, the figures give us an idea of the power with which these substances retain the last part of their hygroscopic moisture, which must be a force opposite to and equal to that with which wetting occurs.

C. VAPOR PRESSURE AND CENTRIFUGAL FORCE METHODS.Other physical measurements have been worked out, some of which are very useful, as for instance HILGARD's hygroscopic coefficient (I6), a measure based on vapor pressure relations, and the moisture equivalent of BRIgGs and McLane (6). The latter is particularly valuable, since BRIGGS and Shantz (7) have shown its relation to various physical and physiological amounts of water. But only one of these measurements can be expressed at present in units which permit a comparison of the soil forces with the osmotic forces of the roots of plants.

\section{PHYSIOLOGICAL MEASUREMENTS}

The most important attempt at a physiological measurement of the soil forces is that of Briggs and Shantz (8), who use the wilting coefficient, or percentage of moisture in the soil at the wilting of the plant, in determining unavailable moisture. However, recent work by Caldwell (9) and by Shive and Livingston (32) shows that within certain ranges the permanent wilting of the plant is a function of the intensity of atmospheric evaporation, and that the wilting coefficient should be rather a measure of the moisture in the plant at the time of wilting than of the moisture in the soil. The constancy of this measure is therefore open to some question, and its value and limitations in physiological studies are to be determined. 
Another important physiological study of soil-moisture relations is Alway's (I) investigation of the relation of non-available water to the hygroscopic coefficient. He has shown that some kinds of plants can remain alive for a considerable time after growth ceases from lack of moisture, while others die rather promptly. This is doubtless one of the main differences between xerophytes and mesophytes. In the case of desert perennial legumes, life was maintained even after the soil moisture had fallen slightly below the hygroscopic coefficient. These results emphasize the need of a measure for the surface force of soils which can be expressed, or at least interpreted, in biological rather than physical terms.

There have been few observations on the relation of seeds to soil moisture. Bogdanoff (3) studied the relation of germinating seeds to soil moisture, and presents many interesting facts. WHITNEY and CAMERon (36) noted the fact that a quantity of cowpeas whose hygroscopic moisture amounted to about I4 per cent, when mixed with an equal quantity of soil which contained I 5 per cent of water, took up I2.I per cent of their own weight, leaving only I.3 per cent of moisture in the soil. That is, the soil was practically air-dry. In the paper referred to (33) I have shown that the initial internal force of air-dry seeds is little short of rooo atmospheres; if this condition be general among air-dry seeds, the behavior of the cowpeas can easily be understood. The relation of seeds to soil moisture and vapor pressure will be considered in more detail later.

\section{Materials and methods}

MATERIAL. - The Xanthium seeds used in the experiments discussed in the following section were secured from plants raised on the experimental grounds of the University of Kansas in I9I3. Originally all of the seeds planted were from a single plant of $X$. pennsylvanicum Wallr. The II9 plants obtained were very uniform in all their obvious characters, and since it has been shown (34) that the intermingled local types of Xanthium are practically isolated by differences in the blooming time of each species, the seeds may be considered as having come from a fairly pure line. This was thought desirable in order that the individual variations of the seeds might be reduced to a minimum, and that consequently 
more uniform behavior might be obtained under experimental conditions. The other seeds used were obtained from local seedsmen under the names given.

The soils used in the major portion of the work will be characterized briefly. As a representative of heavy clay soil, the subsoil of the Oswego silt loam was chosen. Specimens of this subsoil were obtained from Riley County, Kansas, on an area about 2 miles west of Manhattan. The Oswego silt loam is a residual soil derived by weathering from underlying unbedded shales and sandstone, with the shales predominating. Its subsoil forms a hard, compact, brittle soil, with a gray to dark brown color. The average composition as determined by mechanical analysis is given in table $I$.

TABLE I

\begin{tabular}{|c|c|c|c|c|c|}
\hline \multicolumn{4}{|c|}{ SAND } & \multirow{2}{*}{ SiLt } & \multirow{2}{*}{ CLAY } \\
\hline Coarse & Medium & Fine & Very Fine & & \\
\hline 0.4 per cent & 0.5 per cent & 4.4 per cent & 3.2 per cent & 6 r. 3 per cent & 30.4 per cent \\
\hline
\end{tabular}

The moisture equivalent is 35.2 per cent, and the wilting coefficient is I9.I per cent. The general details in regard to the Oswego silt loam and its subsoil may be obtained from the Eighth Report, Field Operations of the Bureau of Soils (II).

As a contrast to the heavy silt clay, a fine quartz sand, the no. 2/o, which is manufactured by the Wausau Quartz Company from quartz rock, was chosen. This grade passes through a I 24mesh screen, and over a I47-mesh screen. The average diameter of the particles is very close to o.10 $\mathrm{mm}$. The chemical analysis given below shows it to be a very pure quartz sand.

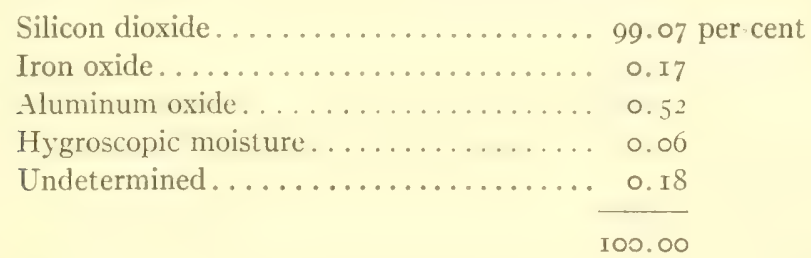

The moisture equivalent is $2.4 \mathrm{I}$ per cent and the wilting coefficient I.3 per cent. 
For a comparative study of the moisture relations of seeds and soils at the wilting coefficient of the soil, a series of soil samples was obtained from Washington, D.C. The necessary data regarding these soils are given in table II.

TABLE II

\begin{tabular}{|c|c|c|c|c|c|}
\hline $\begin{array}{l}\text { Sample } \\
\text { number }\end{array}$ & Locality & Soil type & $\begin{array}{l}\text { Moisture } \\
\text { equivalent }\end{array}$ & $\begin{array}{l}\text { Wilting } \\
\text { coefficient }\end{array}$ & $\begin{array}{c}\text { Hygroscopic } \\
\mathrm{H}_{2} \mathrm{O} \text { (per cent)* }\end{array}$ \\
\hline $\begin{array}{l}5 \ldots \ldots \\
6 \ldots \\
7 \ldots \\
8 \ldots \\
9 \ldots \\
9 \ldots \\
\ldots\end{array}$ & $\begin{array}{l}\text { Yuma, Arizona } \\
\text { Highmore, } \\
\text { South Dakota } \\
\text { North Platte, } \\
\text { Nebraska } \\
\text { North Platte, } \\
\text { Nebraska } \\
\text { Amarillo, Texas } \\
\text { North Platte, Neb. } \\
\text { Akron, Colorado } \\
\text { Yuma, Arizona } \\
\text { Akron, Colorado }\end{array}$ & $\begin{array}{l}\text { Sand } \\
\text { Loam } \\
\text { Very fine } \\
\quad \text { sandy } \\
\text { loam } \\
\text { Loam } \\
\text { Clay loam } \\
\text { Clay loam } \\
\text { Fine sand } \\
\text { Sand } \\
\text { Loam }\end{array}$ & $\begin{array}{r}1.35=0.04 \\
23.79 \pm 0.10 \\
15.33 \pm 0.08 \\
22.84 \pm 0.03 \\
29.65 \pm 0.02 \\
30.08 \pm 0.04 \\
5.90 \pm 0.05 \\
1.53 \pm 0.01 \\
19.91 \pm 0.12\end{array}$ & $\begin{aligned} 0.73 & =0.02 \\
12.93 & \pm 0.05 \\
8.33 & =0.08\end{aligned}$ & $\begin{array}{l}\text { I. } 836 \\
2.28 \\
3.82 \\
5.21 \\
0.75 \\
0.218 \\
2.3\end{array}$ \\
\hline
\end{tabular}

* The hygroscopic moisture was determined at the time of use in an or dinary dry oven. The other figures were furnished by Dr. LYMAN J. BRIGGs, of Washington, D.C.

Methods. - While the internal forces of Xanthim seeds have been approximated by osmotic means, many seeds lack semipermeable coats. For such seeds a vapor pressure method has been used which gives results which are in a way comparable to the osmotic measurements. It consists essentially in measuring the vapor pressure equilibrium of the air-dry seeds over sulphuric acid of varying strength, and calculating the internal pressure of the seed from the vapor pressure of the solution over which it was found to be in equilibrium. Owing to our slight knowledge of the concentrated solutions and of the exact relations of colloids to water vapor, the calculations can give only a rough estimate of the internal forces of the seeds, but they are near enough to the osmotic determinations to be of great interest.

The sulphuric acid series was chosen with some reference to the LANDOLT-BöRNsteIn tables to facilitate calculation. Beginning with water, the series included $16,26.5,35,39,50,54,57 \cdot 5$, $66,73,84.5$, and 96-99 per cent $\mathrm{H}_{2} \mathrm{SO}_{4}$. These fluids were placed in tightly sealed, small, wide-mouthed bottles. The seeds to be 
tested were suspended in shallow paper baskets a few millimeters above the surface of the acid, the baskets being hung on cotton threads fastened to the corks with carna-uba wax. All metallic condensers were thus avoided. After the seeds were carefully weighed and arranged, the bottles were sunk in a trough of running water to prevent any considerable changes in temperature. Condensation effects due to change of temperature could not occur except over water, for MitscherLich (2I) has shown that even Io per cent sulphuric acid will prevent deposition of dew in determining hygroscopic coefficients of soils. It may be questioned whether the inclosed space actually reaches the vapor pressure of the solution, for, as HiLgard (I7) points out, it is most difficult to secure complete saturation in the case of water vapor. However, the space of air to be brought into equilibrium with the solution vapor pressure in these experiments is very small, and it seems probable that the whole system of liquid, air, and seed comes to an equilibrium pressure in the time of the experiment, except possibly in the case of water. After allowing I5 days for reestablishment of equilibrium by the seeds, the point of no change was determined by weighing.

The osmotic pressure of the sulphuric acid is roughly determined by the use of the vapor pressure formula $P=\frac{f-f^{\mathrm{x}}}{f} \cdot \frac{S R T}{M}$, in which $f$ is the vapor pressure of pure water at the temperature of the experiment, $f^{\mathrm{x}}$ the vapor pressure of the acid, $M$ the molecular weight of the solvent's vapor, $T$ the absolute temperature, $S$ the density of the sulphuric acid, and $R$ the gas constant. The osmotic pressure $(P)$ is given in grams per square centimeter, and must be reduced to atmospheres. 'This formula has been developed for dilute solutions and does not hold accurately for high concentrations, but there are at present no data on which to base more accurate estimations. The boiling-point method yields a result close to that given by this formula for sulphuric acid, as will be shown later.

The earliest soil measurements were made with no. 2/o sand. Seeds of known weight were packed firmly in sand of known water content in paraffined wire baskets, and allowed to come to 
equilibrium. The tests were confined finally to the region of soil moisture from air-dry to the wilting coefficient, for with a higher moisture content the seeds always became saturated with water. In the case of this sand it was not until the water content was reduced to about I per cent that "a noticeable "back pull" was developed by the soil.

This method is obviously open to the criticism that friction retards the movement of water in dry soils, and that the seeds therefore do not reach actual equilibrium with the total soil mass, but only with the soil lying very near them. In order to meet this difficulty a rotation method was adopted which brings the seeds constantly into contact with fresh soil particles.

A definite amount of dry soil, usually $60 \mathrm{gm}$., was taken, and the desired amount of, water thoroughly mixed with it. In this condition the soil was divided finely enough to pass through a $2 \mathrm{~mm}$. sieve. The moist soil was then placed with dry seeds in a wide-mouthed $200 \mathrm{cc}$. bottle, without completely filling it, so that rotation would constantly mix the soils and seeds. The bottles were carefully sealed with heavily shellacked corks to prevent loss of water during the period of rotation.

These bottles were arranged on rotating wheels, driven by a motor and controlled by a speed reducer (fig. I). The range from air-dry to wilting coefficient was divided into Io fairly equal divisions, giving II tests in each series. The rotation was continued for I5 days, this time having been chosen after making tests as to the effect of differences in duration of the experiment on the amount of intake by the seeds. For instance, no. 2/o sand with about 0.2 per cent moisture added permitted an intake of 22 per cent of their weight by the seeds in 5 days, and a parallel test showed $2 \mathrm{I} .7$ per cent intake in to days. Fifteen days, therefore, seems ample time for the establishment of equilibrium. At the end of the time the bottles were opened, and the seeds very rapidly separated from the soil and brushed free of all dust with a camel's-hair brush. The soil and seeds were both placed in weighing bottles as quickly as possible, to prevent serious loss of water by evaporation. The soil was weighed carefully and dried at $104^{\circ} \mathrm{C}$. until loss ceased. The seeds also were weighed. The 
moisture content of the seeds and soils at the time the bottles were opened expressed the equilibrium relation of that soil moisture content.

Since means are at hand for determining the internal force of the seed at practically any moisture content, it is possible to determine

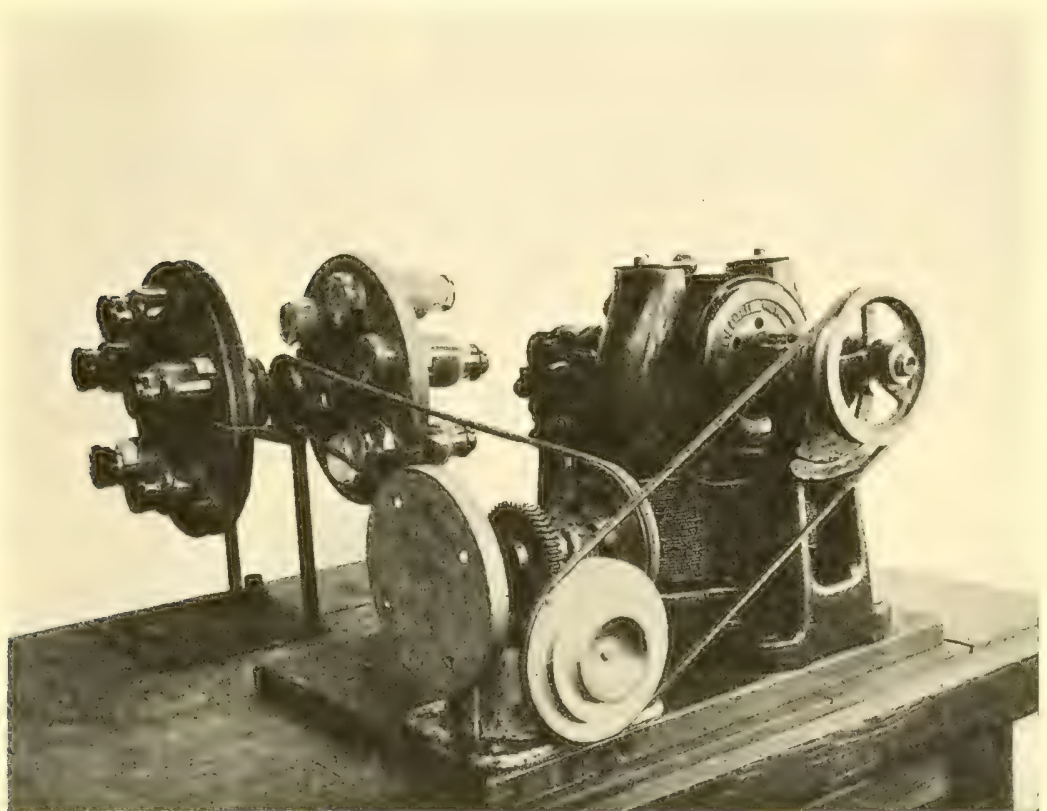

FIG. I.-Rotator used in these experiments, with motor and speed reducer.

from the data the forces of the soils. which are in equilibrium with those of the seed.

The principal sources of error lie in the fact that moist soils and seeds cannot be handled in ordinary atmospheres without some loss by evaporation during the handling, and in the fact that hot-air ovens for drying are not as accurate as vacuum driers. No claim is made for greater accuracy than these methods will permit. Of course, every precaution was taken to reduce errors to a minimum, and the work was done with the greatest speed and accuracy possible. It is confidently believed that the results to be obtained by more refined methods and more expensive 
apparatus would in no way change the nature of the conclusions to be drawn from the results.

\section{Experimental results}

A. Measurement of the seeds.-The measurement of the internal forces of Xanthium seeds by means of $\mathrm{NaCl}$ and $\mathrm{LiCl}$ solutions has been repeated and extended with full confirmation of the previously published results. The data are presented in tabular form for the sake of convenience in table III, and these figures may serve as a basis of comparison in the soil experiments, where the surface forces of the soil particles, instead of osmotic pressure, are pitted against the internal forces of the seed. The data were secured with the lower seeds of Xanthium pennsylvanicum.

TABLE III

Moisture intake of Xanthium seeds in osMotic solutions; teMPERAture $23.5^{\circ} \mathrm{C}$; ; INTAKE IN PERCENTAGE OF AIR-DRY WEIGHT

\begin{tabular}{|c|c|c|c|c|c|c|c|}
\hline $\begin{array}{l}\text { Solutions volume } \\
\text { molecular }\end{array}$ & I hour & 4 hours & 7 hours & ro hours & 24 hours & 48 hours & $\begin{array}{l}\text { Osmotic } \\
\text { pressure in } \\
\text { atmos- } \\
\text { pheres }\end{array}$ \\
\hline $\mathrm{H}_{2} \mathrm{O} \ldots$ & I6.39 & $44 \cdot 3^{8}$ & 48.78 & $50.3^{8}$ & 5 I. I8 & 5 I. $5^{8}$ & 0.0 \\
\hline o. I M-NaCl. & I6. 79 & .43 & 45.87 & 46.48 & 46.39 & 46.33 & 3.8 \\
\hline $0.2 \mathrm{M}-\mathrm{NaCl}$. & I7. 12 & $3^{8} .67$ & 45.00 & $45 \cdot 57$ & 45.93 & $45 \cdot 52$ & $7 \cdot 6$ \\
\hline $0.3 \mathrm{M}-\mathrm{NaCl}$. & I6.07 & 34.05 & 40.75 & 4 I. 95 & 42.24 & 42.05 & II . 4 \\
\hline $0.4 \mathrm{M}-\mathrm{NaCl}$. & $14 \cdot 36$ & 3 I. 2 I & 38.08 & 39.97 & 40.33 & 40.27 & I5. 2 \\
\hline o. $5 \mathrm{M}-\mathrm{NaCl}$. & I3. 36 & 30.26 & 35.87 & 38.08 & 38.70 & 38.98 & 19.0 \\
\hline $0.6 \mathrm{M}-\mathrm{NaCl}$ & I3.80 & 25.57 & $3^{2} .4 \mathrm{I}$ & $33 \cdot 57$ & 34.77 & 35.18 & 22.8 \\
\hline $0.7 \mathrm{M}-\mathrm{NaCl}$. & $13 \cdot 32$ & 26.29 & 30.99 & 31.73 & 32.79 & 32.85 & 26.6 \\
\hline $0.8 \mathrm{M}-\mathrm{NaCl} \ldots$ & I3. I3 & 25.22 & $29.2 \mathrm{I}$ & 29.95 & 31.12 & 31.12 & 30.4 \\
\hline $0.9 \mathrm{M}-\mathrm{NaCl}$. & I $2.5^{8}$ & $24 \cdot 34$ & 27.64 & 28.95 & 29.14 & 29.79 & $34 \cdot 2$ \\
\hline I. o $\mathrm{M}-\mathrm{NaCl}$. & II. 90 & 22.92 & 25.42 & 26.48 & $26.2 I$ & 26.73 & 38.0 \\
\hline 2.0 $\mathrm{M}-\mathrm{NaCl}$. & 8.19 & 14.55 & 18.25 & r 8.43 & 18.60 & I 8.55 & 72.0 \\
\hline 4.० M-NaCl. . & $4.8 \mathrm{I}$ & 8.3 & 9.84 & 10.08 & II ., 0 & II. 76 & I30.0 \\
\hline Sat: $-\mathrm{NaCl} \ldots$ & $3 \cdot 42$ & 4.94 & $5 \cdot 24$ & 5.84 & $6.2 I$ & 6.35 & 375.0 \\
\hline Sat. $-\mathrm{LiCl} . .$. & -0.67 & -0.77 & $-0.5^{8}$ & -0.58 & $-0.5^{8}$ & -0.29 & 965.0 \\
\hline
\end{tabular}

The results obtained by the vapor pressure method over sulphuric acid are shown in table IV, and some of the curves of moisture intake showing the point of natural equilibrium are shown in figs. 2 and 3 .

As the table and curves show, the seeds are initially in moisture equilibrium with sulphuric acid of 46-54 per cent strength. In general the seeds which have carbohydrate reserves in greatest 
abundance seem to have a somewhat lower equilibrium point than those with high fat and protein content.

The osmotic pressure of the sulphuric acid calculated from the vapor pressure formula given runs from rooo to I350 atmospheres. The validity of the vapor pressure formulae will be discussed later. If colloids absorbed as much moisture from a saturated atmosphere as from water, it might be safe to assume that the internal force of the seeds is equal to the osmotic force of the solution. But if vON SCHRÖDER's work holds for all colloids, this vapor pressure method may give abnormal values. If the colloids always tended to take up more water when in contact with the fluid, above the equilibrium point as well as below, the values given here would be too low, as the equilibrium point would be shifted toward the stronger acids. If, on the other hand, intake is increased below the equilibrium point, and loss is increased correspondingly above the equilibrium point, the shape of the curve would be changed, but the equilibrium point would remain fixed.

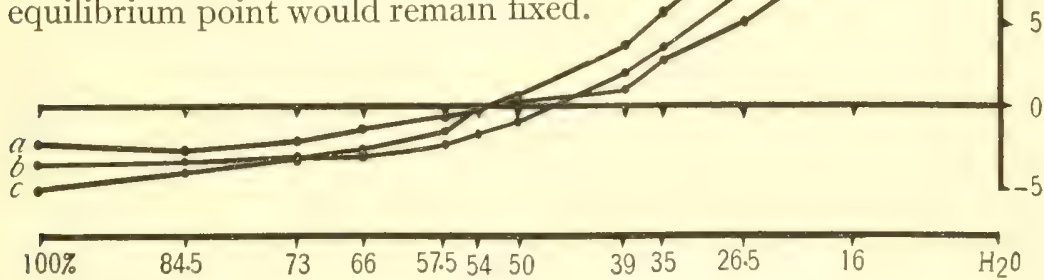

FIG. 2.-Curves of moisture equilibrium of seeds suspended over sulphuric acid: $a$, Pisum sativum; $b$, Stowell's evergreen sweet corn; $c$, Xanthium pennsylvanicum; abscissae, strength of sulphuric acid; ordinates, moisture intake by seeds in percentage of air-dry weight.

The values run higher with the $\mathrm{H}_{2} \mathrm{SO}_{4}$ than with the lithium chloride solution, as given in table III. There is one source of possible discrepancy which needs to be mentioned. The vapor pressure tests were all made in Kansas, where the climate averages drier than at Chicago, while the osmotic measurements were all 


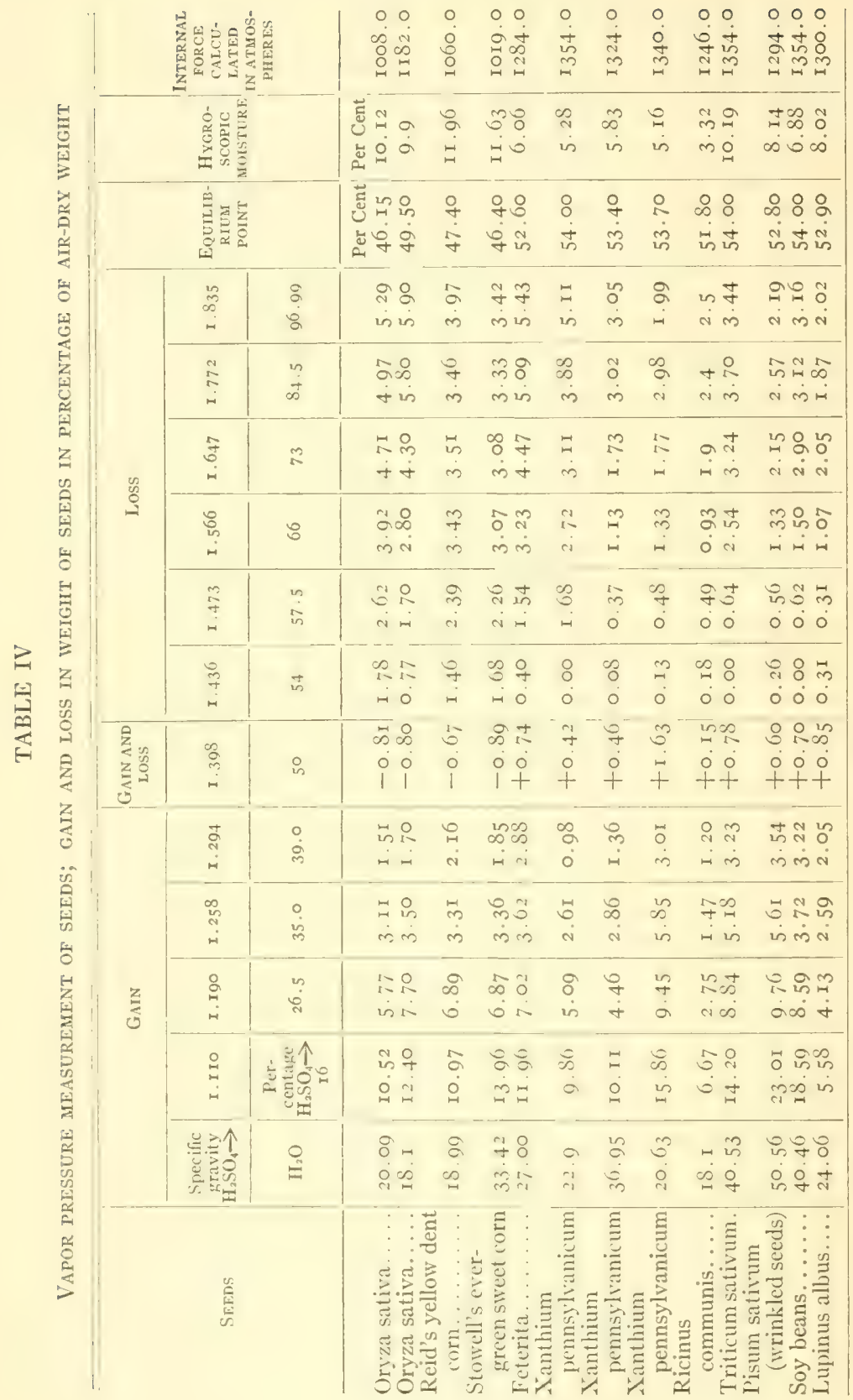


made at Chicago. The hygroscopic moisture of the seeds was uniformly near 5.5 per cent in Kansas, ${ }^{x}$ while at Chicago the hygroscopic moisture was rarely less than 7 per cent, usually above. The equilibrium point would naturally run higher, therefore, in a drier climate. However, it is not claimed that the discrepancy would entirely disappear if repeated with seeds of the same moisture content.

There seems to be little doubt as to the high osmotic strength of the sulphuric acid, for the boiling-point method of measuring osmotic pressure gives a value in close agreement with those just given. The boiling point of 53 per cent $\mathrm{H}_{2} \mathrm{SO}_{4}$ is $128.5^{\circ} \mathrm{C}$. If for each rise of $0.52^{\circ} \mathrm{C}$. we may assume an osmotic pressure equal to one mole of dissolved substance (HöBER, Phys. Chem. p. I9), this strength of sulphuric acid should have an osmotic pressure of 1227 atmospheres.

At all events, it is safe to conclude that air-dry seeds possess a very high internal attraction for water

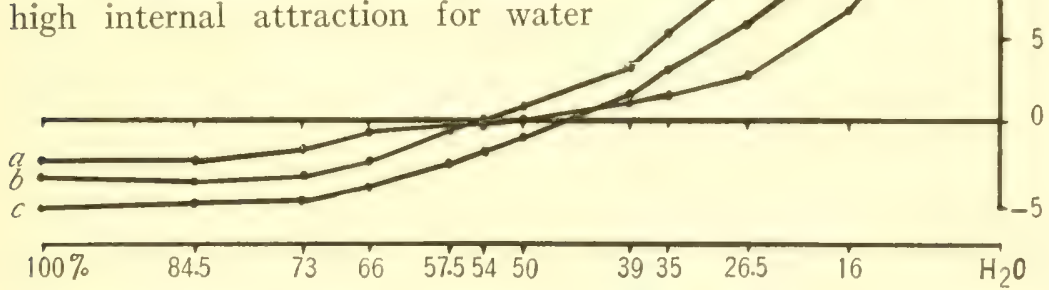

FIG. 3.-Curves of moisture equilibrium of seeds suspended over sulphuric acid: a, Ricimus communis; b, Triticum sativum; c, Orysa sativa; abscissae, strength of sulphuric acid; ordinates, moisture intake by seeds in percentage of air-dry weight.

which at the initial moment of intake is but little short of rooo atmospheres. Owing to uncertainty of the figures for sulphuric acid, only those obtained by direct contact with osmotically active solutions will be used as a standard for the following soil experiments:

I Seeds sent to Washington were dried in the vacuum oven by Mr. A. B. CAsrBELL. Upper seeds averaged 5.48 per cent of the absolute dry weight, and lower seeds averaged 5.72 per cent of their absolute dry weight. 
B. The surface forces of SOILS.- I. The Oswego silt loam.A number of tests were made with the subsoil of the Oswego silt loam, the results of 4 of which are shown in table V. The air-dry soil apparently holds its moisture with about the same force as do air-dry seeds, a result one might expect, since both are in moisture equilibrium with the same atmosphere at air-dry.

\section{TABLE $V$}

RELATION OF SOIL MOISTURE IN SUBSOIL OF OSWEGO SILT LOAM TO WATER INTAKE BY SEEDS OF Xanthium pennsylvanicum

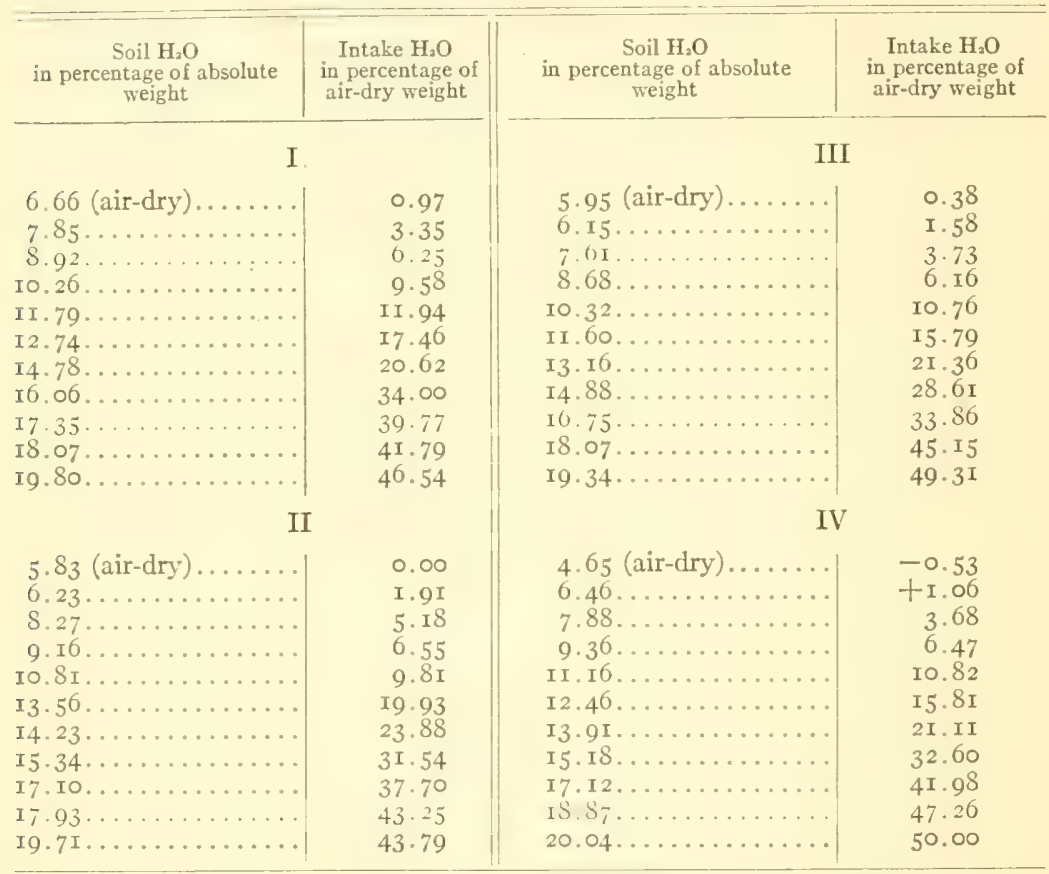

As soil moisture is increased, the moisture intake by the seeds increases at a much more rapid rate, until the approaching saturation of the seed begins to cut down the absorption rate. This happens as the soil moisture approaches the wilting coefficient. Reference to fig. 4 will make the relationship of soil moisture content to seed intake clear. 
The general situation is strikingly illustrated by table VI, which combines the results of the 4 experiments of table $\mathrm{V}$. While there are a number of discrepancies, as one might expect, it is evident that the method can be used in measuring approximately the forces residing on the surfaces of soil particles at various soil moisture contents. For instance, when this soil contains about 9.36 per

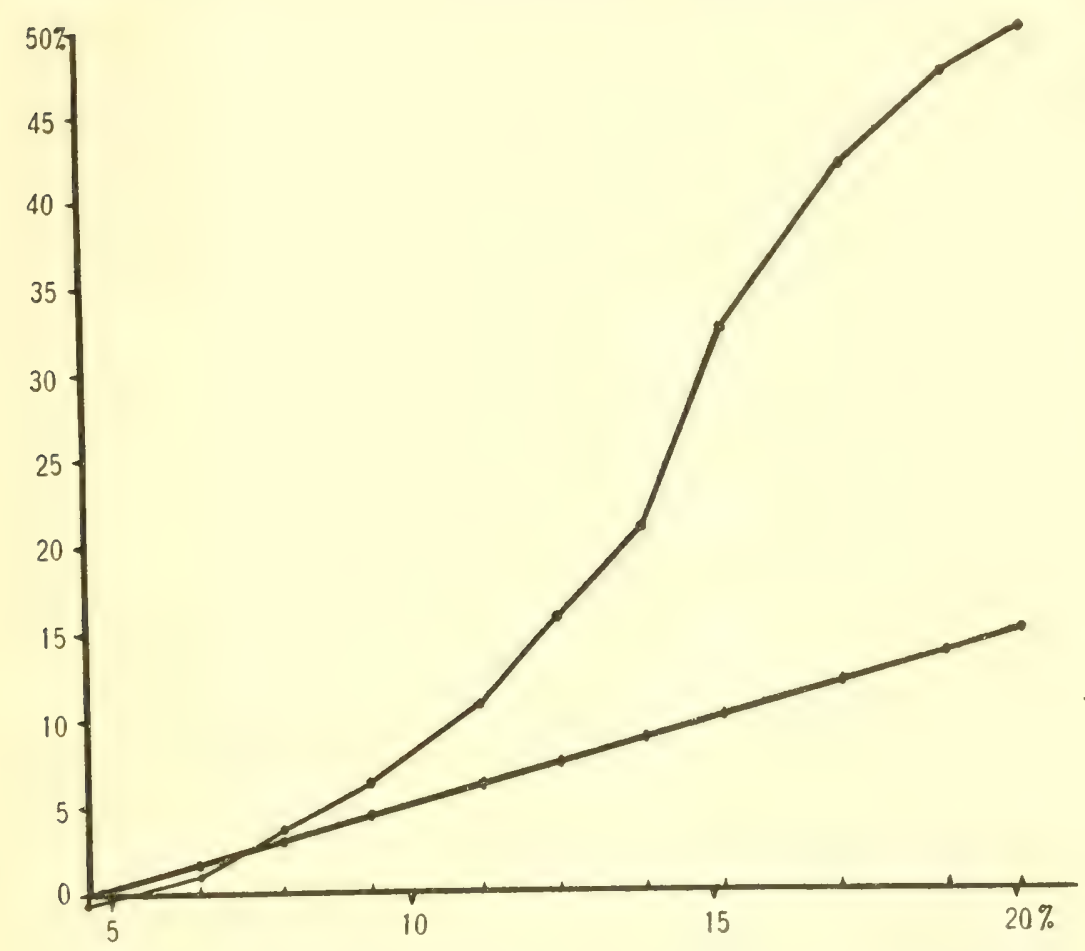

FIG. 4-Curves showing relation of moisture intake by seeds to increasing soil moisture, plotted from experiment 4 , table $\mathrm{V}$; abscissae, percentage of soil moisture in terms of absolute dry weight; ordinates, percentage of increase of soil moisture above air-dry weight for the soil moisture curve (straight), and percentage of intake by seeds in terms of their air-dry weight.

cent of moisture ( 3.5 per cent above air-dry), it is in moisture equilibrium with seeds at 6.47 per cent above their air-dry weight. The seeds attain about the same equilibrium point with saturated $\mathrm{NaCl}$ solution, which has an osmotic pressure of 375 atmospheres, 
from which it follows that the surface force of the soil particles at the given moisture content is also approximately 375 atmospheres.

TABLE VI

RELATION OF SOIL MOISTURE TO INTAKE BY SEEDS; DATA OF TABLE V. COMBINED

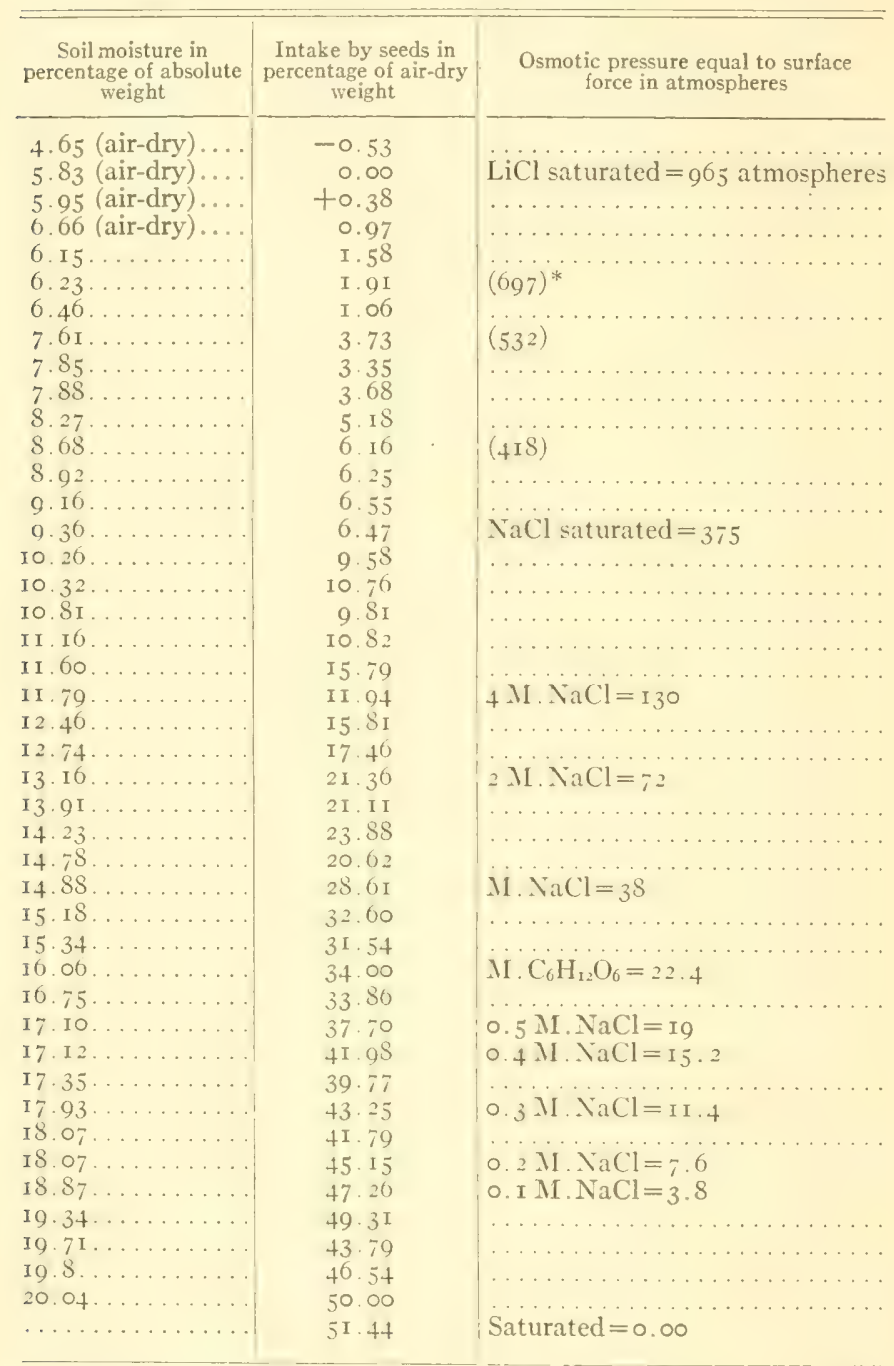

* Values in parenthesis calculated from the curve of moisture-bolding power of the soil as determined by the known values. 
When the soil moisture reaches 6 per cent above air-dry, the moisture intake by seeds indicates a force equivalent to $4 \mathrm{M} . \mathrm{NaCl}$ solution, which is estimated to exceed I30 atmospheres. At II per cent above air-dry the holding power of the soil has fallen to 22.5 atmospheres approximately.

In this manner, comparing the percentage intake from the soil with that from the solutions, as given in table III, one may estimate the surface force for any given moisture content of the soil, each soil type, of course, having specific relations. If it were possible to make absolutely accurate determinations for several points in the curve of moisture intake by seeds, as related to the curve of moisture increase in a particular soil, it would be a simple mathematical problem to calculate the exact water-holding power of the soil particles at any soil moisture content whatsoever for that soil.

2. The no. $2 / 0$ sand.-By preliminary tests ranging from $\mathrm{I} 7.5$ per cent to I per cent of moisture it was found that there was no significant water-holding power in this sand until the moisture content fell to less than 2 per cent. At I per cent of soil moisture the seeds took in over 45 per cent of their own dry weight.

The results of a series of tests running from air-dry (O. I4 per cent) to a little beyond the wilting coefficient ( $\mathrm{I} .3$ per cent) are shown in table VII.

TABLE VII

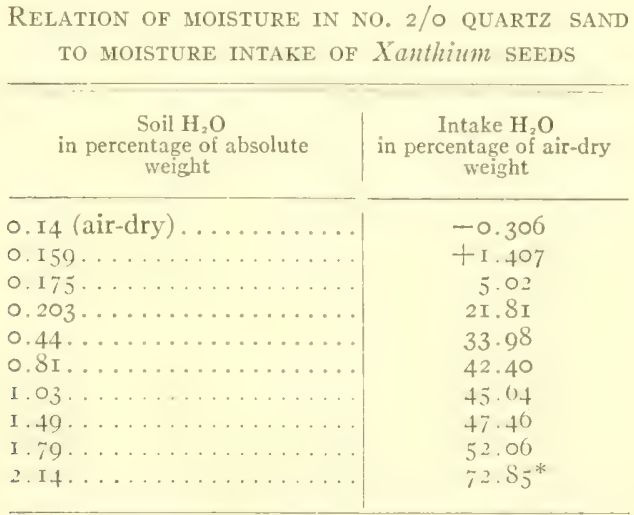

*Four seeds showing incipient germination, hypocotyls averaging $3 \mathrm{~mm}$. long. 
In this sand the very rapid decrease in the force with which its particles hold water as moisture content increases stands in sharp contrast to the slower decrease in the heavy clay subsoil. While the air-dry sand gives the same kind of result as the air-dry clay, by the time the sand contains 0.44 per cent of water the seeds secure as much water as they do in a molecular solution of non-ionizable salts. This indicates a force of 22.4 atmospheres.

3. Various soil types. - The results obtained with the subsoil of the Oswego silt loam and the no. 2/o sand suggested that there might be a general relationship between soils and seeds as regards the amount of moisture seeds will absorb at the wilting coefficient of the soil, whatever value the wilting coefficient might have. To clear up this point, the soil types of table II were used. Each soil was brought as nearly to the wilting coefficient as possible by addition of water. The closeness of the experimental conditions to the wilting-coefficient determinations is shown in columns 3 and 4 of table VIII.

TABLE VIII

RELATION OF WILTING COEFFICIENT TO MOISTURE INTAKE BY SEEDS

\begin{tabular}{|c|c|c|c|c|}
\hline Soil types & $\begin{array}{l}\text { Percentage of } \\
\text { hygroscopic } \\
\text { moisture }\end{array}$ & $\begin{array}{c}\text { Percentage of } \\
\text { wilting coefficient }\end{array}$ & $\begin{array}{l}\text { Percentage of } \\
\text { soil } \mathrm{H}_{2} \mathrm{O}\end{array}$ & $\begin{array}{l}\text { Percentage of } \\
\text { seed intake }\end{array}$ \\
\hline 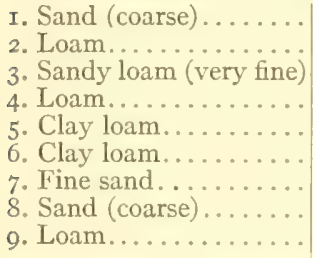 & $\begin{array}{l}0.205 \\
3.130 \\
1.836 \\
2.280 \\
3.820 \\
5.210 \\
0.750 \\
0.218 \\
2.30\end{array}$ & $\begin{array}{r}0.73 \pm 0.02 \\
12.93 \pm 0.05 \\
8.33 \pm 0.08 \\
12.41 \pm 0.02 \\
16.12 \pm 0.01 \\
16.34 \pm 0.02 \\
3.21 \pm 0.03 \\
0.83 \pm 0.01 \\
10.82 \pm 0.06\end{array}$ & $\begin{array}{r}0.65 \\
\text { I } 2.66 \\
7.86 \\
\text { I } 3.30 \\
16.01 \\
17.78 \\
3.19 \\
0.80 \\
10.51\end{array}$ & $\begin{array}{l}34.44 \\
49.02 \\
48.38 \\
49.01 \\
49.49 \\
47.31 \\
49.77 \\
40.98 \\
50.42\end{array}$ \\
\hline
\end{tabular}

The percentage of moisture taken up by dry seeds placed in each soil is shown in the last column of the table. With the exception of the two sands from Yuma, Arizona, which are coarse, the results are fairly uniform. In two cases the soils adhered badly to the seeds, making accurate work very difficult; but corrections were made as carefully as possible. In all the other soils the seeds remained clean, or were easily brushed free of adhering particles. The average intake for the 7 types, excluding the coarse sands, is 
approximately 49 per cent, and this average agrees rather closely with the intake in the Oswego silt loam subsoil and in the no. 2/o sand at their wilting coefficients. This probably means that the wilting coefficient represents a fairly definite water-holding power for the soil particle, regardless of its size. By comparison of the results given in table VIII with those given in tables III and VI, it is seen that the "back pull" of the soil particles, the force with which they withhold water from seeds and plants at this critical moisture content, is not more than the equivalent of o. IM. NaCl solution, or 3-4 atmospheres. This value is surprisingly low.

\section{Discussion}

In this paper the term internal forces of seeds is used to designate the resultant of all forces within the seed tending to cause intake of moisture; and by surface forces of soils is meant the resultant of all the forces of adhesion, cohesion, surface force, etc., as determined by size, chemical composition, and character of the surface of the soil particles, which cause the soil to retain moisture.

In order to make clear the nature of the problems involved in this work we shall first consider rather fully the moisture relations between seeds and their environment, and then the moisture relations of soils to seeds and to the root hairs of living plants. A careful study of the moisture relations existing between organic bodies, like seeds, and the atmosphere, the soil, and osmotic solutions, if the seeds have semipermeable coats, convinces one that the entrance or exit of water from the seed is due to the interplay of such internal forces as capillarity, imbibition force, colloid hydration forces, etc., with external forces such as atmospheric evaporation, the surface forces active on soil particles, osmotic pressure, etc., according to the environment of the seed. Moisture flows into or out of the seed as one or the other of these sets of forces is the greater. Movement of water continues only until the two forces, unequal at the start, become equal. This establishes moisture equilibrium, and further movement of water must be consequent to some disturbance, external or internal, of the balanced condition of forces. Moisture equilibrium may obtain at any moisture content of the seed, if only the two forces are equal. 
The attempt to measure the internal forces of seeds with semipermeable coats by means of osmotic solutions was based upon this conception of the moisture relations, and on the assumption that the total osmotic pressure of the solution is transmitted through the membrane as force when pitted against the internal forces of the seed through the agency of the semipermeable coat. The results of this attempt have been highly satisfactory, and I can see no good reason for doubting that the internal forces of air-dry seeds are approximately equal to 900-I000 atmospheres.

The vapor pressure method, using sulphuric acid, involves another assumption whose validity may be a little more questionable. It is generally admitted that the osmotic pressure of a solution can be calculated with some degree of accuracy from its vapor pressure. I have assumed in addition that the vapor pressure of the seed hydrogels measured against the vapor pressure of strong solutions can be used as a measure of the internal forces of the seed. The assumption seems reasonable enough, but it would be difficult to offer definite proof of its validity at present.

The principal difficulty with the vapor pressure method is the uncertainty as to the osmotic pressure of sulphuric acid. It may seem quite unwarranted to some even to think of estimating the osmotic pressure of strong sulphuric acid by means of a formula, knowing as little as we do of all the factors which enter into the problem in this case, and knowing that these formulae have all been developed for the dilute "ideal" solutions. I realize fully the danger of basing any conclusions upon results obtained by such precarious methods, and offer the results merely for their suggestive value. The formula I have used for calculating the osmotic pressure from the vapor pressure is that given by WALKER (35), with $S$ representing the density of the solution rather than that of the solvent. This is necessary in order to make the formula fit a concentrated solution with high density. This same formula has been used by others for the same purpose; as by DRABBLE and DRABBLE (I2).

- Attention is called to a difference in the formulae given by NERNST (24) and WALKER. In WALkER's discussion, $\frac{f-f^{x}}{f}$ repre- 
sents relative lowering of the vapor pressure of the solution as compared with that of water. His formula actually gives the relative lowering. Nernst, however, uses $\frac{p-p^{1}}{p^{1}}$ for this factor in the equation, and with concentrated solutions it is quite a different thing. In a concentrated solution, where the relative lowering of the vapor pressure is 0.75 , NERnst's formula will give a value for the osmotic pressure 4 times as great as that given by WALKER'S formula.

In the third English edition of NERNST he gives an equation for this calculation which he claims gives a very exact value for the osmotic pressure from vapor pressure. His equation is as follows:

$$
P=\frac{0.082 \mathrm{I} \cdot T . \quad 1000 S}{M} \cdot \ln \frac{p}{p^{\mathrm{x}}}
$$

The physical chemists claim that this formula should hold in so far as it includes the factors involved. But even this exact formula does not take care of the change in volume occurring on dilution of the acid, nor for the heat of dilution, which is very considerable in the strong acid solutions over which equilibrium of moisture vapor was obtained in these experiments.

I have chosen to use WALKER'S formula because it actually gives the relative lowering of the vapor pressure, as it is supposed to do. However, it is perfectly clear from this discussion that the osmotic pressure of sulphuric acid of any given concentration, especially of high concentration, cannot be measured accurately by any single vapor pressure formula suggested to date.

The measurements made over sulphuric acid give values, therefore, which are merely suggestive. They indicate that the internal forces of air-dry seeds of all kinds are very high, and confirm the high values obtained by the osmotic solution method. But the latter method only, I believe, can be relied upon for the measuring of the internal forces of seeds until the vapor pressure relations are more perfectly understood.

The main conclusion in regard to these seed measurements may be stated briefly thus: It is possible, with seeds having a perfectly semipermeable coat, to measure the water-attracting internal forces 
residing in the seed substance at any moisture content between saturation and air-dry. The actual values for this range in Xanthium seeds are given in the last column of table III.

The results obtained by measuring the soils with measured seeds are of the greatest interest. While it is important to have means of determining in terms of atmospheric pressure the water-retaining power of soils at any degree of dryness between saturation and airdry, it is still more important to understand the moisture relations of the plant to the soil at and just below the wilting coefficient. Does wilting occur because capillary soil forces and osmotic root forces reach equilibrium? If so, why should BRIGGS and SHANTz (8) have found a uniform wilting coefficient for all kinds of plants when we know that root cells vary somewhat in osmotic concentration from species to species? And why should this uniformity fail in the presence of intense evaporation, as shown by CALDWELL (9), and by Shive and Livingston (32)? These questions, and the discrepancies between the excellent work done at Washington and at Tucson can probably be answered intelligently, and explained in the light of these experiments.

The moisture equivalent of a soil is the percentage of water left in the soil after centrifuging for a certain time under a force of rooo gravities, a force about equal to one atmosphere. We have been accustomed to find the wilting coefficient empirically, or to divide the moisture equivalent by I.84. But we have not known how much greater are the soil forces at the wilting coefficient than at the moisture equivalent. From the results obtained, the pressure value of the wilting coefficient seems to be about 4 atmospheres.

As the soil becomes drier and drier, the forces become greater and greater, until on the approach of air-dry conditions a very small change in moisture content makes a very large change in the forces involved. The increase of the force with decreasing soil moisture is shown graphically in fig. 5, which shows the curve of increasing force for the Oswego silt loam subsoil, and for no. 2/o sand. The difference in the curves for clay and sand is striking. In the clay, where the surface films are relatively thick, the force decreases very slowly for a considerable distance. But as the films become very thin, the surface force and forces of adhesion of water 
to particles become very great. This force would reach its maximum presumably when the particles were surrounded by a film of water just one molecule thick. The curve for the sand is very similar, except that the period of slow increase of the soil forces is very short, and that the whole curve lies much nearer to the absolutely dry condition. These relations, of course, are conditioned mainly by the size of the particles.

Let us see now how the soil forces at the wilting coefficient compare in value with the average osmotic pressure of the root hairs. A few years ago Hill (I8) showed that the root hairs of Salicornia can in a measure accommodate themselves to changes in the osmotic concentration of the surroundings, through increase or decrease of the cell sap concentration parallel to the changes in the environment. That the cell sap of leaves and other exposed parts increases in concentration with xerophytic habitat has been shown by DrabBle and LAKE (I3), Fitring (14), and others. The general conclusion reached by Drabble and Drabble (I2), that the osmotic strength of cell sap varies with the physiological scarcity of water in any area, seems most reasonable, and it doubtless

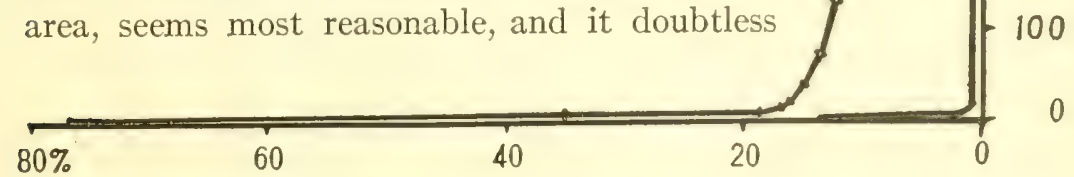

FIG. 5.-Curves showing increase in the surface forces of soils as drying proceeds; to the left, for subsoil of the Oswego silt loam; to the right, for no. $2 / 0$ sand.

holds true of root cells under xerophytic soil conditions. As the soil becomes deficient in water supply, and the surface forces are rapidly increasing in magnitude, we might then expect this increased force of the soil to be paralleled by increase in the osmotic forces of the root hairs, owing to progressive concentration of the cell sap. Such increase might amount to many atmospheres. 
The most careful, extensive, and valuable study of the osmotic pressure of the sap of root cells under ordinary conditions of soil moisture which has been made up to the present is that by HANNIG (I5). He finds that the average root cell sap pressure for 64 species of plants is $0.2 \mathrm{IM}$. $\mathrm{KNO}_{3}$, or equivalent to 7 or 8 atmospheres. It is seen, therefore, that the water-holding power of the soil at the wilting coefficient is only about half that of the average osmotic pressure of the sap of the root cells. Certainly wilting at the wilting coefficient cannot be due to lack of water, for seeds come within a few per cent of taking up as much moisture at the wilting coefficient as when placed in water itself. Nor can it be due to equalization of forces between root hair and soil water, for there is still a gradient of 4 atmospheres of force in favor of the plant. Moisture and gradient for movement of water toward the plant are both present, and yet the plant wilts!

Even in cases where the soils are drier than the wilting coefficient, the accommodation of the root hairs mentioned above would probably maintain this gradient of a few atmospheres in favor of moisture intake. This idea is strongly supported by unpublished work of Miss EDith A. Roberts, who, working in this laboratory, has shown that seedlings of mustard and radish grown in sugar solutions develop root hairs with osmotic pressures usually about 4 atmospheres in excess of the medium in which they grow, the same amount of excess as this gradient at the wilting coefficient. This relationship of internal to external forces was maintained, in her work, up to volume molecular solutions of cane sugar. It is exceedingly probable, therefore, that as soils dry out beyond the wilting coefficient the root hairs maintain an osmotic pressure a few atmospheres in excess of the soil forces until those forces become relatively very high. Nevertheless, permanent wilting occurs within a narrow range of soil moisture under moderate conditions of evaporation.

There seems to be but one reasonable explanation for this situation. The wilting of plants at the wilting coefficient of the soil must be due to the failure of water movement from soil particle to soil particle, and from these to the root hairs, rather than from lack of moisture or gradient. This does not mean complete cessation 
of movement of film water toward the plant. It is a question of rates. Evaporation continues from the leaves in accordance with atmospheric conditions somewhat regardless of conditions below the soil surface. At the wilting coefficient the film water becomes so stable, and the friction of movement becomes so great, that the rate of movement of water toward the root is quite inadequate to meet the needs of the plant, and permanent wilting ensues.

It becomes clear at once why BRIGgS and Shantz, working under rather uniform conditions of evaporation, found the same wilting coefficient for all kinds of plants in a given soil, regardless of variability of root sap concentration and other variable factors, for these variables do not affect the point at which capillary movement of water over the soil particles ceases to be effective for the plant. This is determined by the physical properties of the soil, the fineness of the particles being the chief factor. We should expect, therefore, this uniform behavior under moderate conditions. On the other hand, when the evaporation rate is very intense, the plant might be caused to wilt permanently before this wilting coefficient is reached, owing to the fact that after all it is a question of rates. The rate of movement in the soil fails to be adequate sooner.

In concluding this discussion, may I suggest that the methods used and the conclusions reached in this work should receive very critical consideration by plant physiologists, soil physicists, and all others interested in these problems. We have lacked even the most elementary facts concerning these important moisture relations of the soil. This is a first attempt to throw light upon an unexplored region of soil physics. It is hoped that other methods may be devised for testing the correctness of the conclusions reached by the methods presented here. The apparatus is quite simple and easily used. If the results obtained can be fairly substantiated by other methods, the method will be exceedingly valuable in physiological and ecological investigations of many kinds.

\section{Summary}

I. The force with which the seeds of Xanthium pennsylvanicum absorb water has been measured by two methods: (a) osmotic 
solutions, and (b) vapor pressure equilibrium. The osmotic method is at present the more reliable.

2. The air-dry seeds of Xanthium show an initial attraction for water of nearly 1000 atmospheres.

3. The attraction which exists at any moisture content of the seed between air-dry and saturation can be approximated. Table III gives the data.

4. The seeds have in turn been used to measure the complex moisture-holding forces of soils, with the following results:

a) The air-dry subsoil of the Oswego silt loam holds its hygroscopic moisture with about the same force as an air-dry seed, that is, about Iooo atmospheres.

b) As the moisture content of the soil increases, the surface force decreases rapidly. When about 3.5 per cent of water has been added to the air-dry soil, the force remaining is about 375 atmospheres. When the soil moisture reaches 6 per cent above air-dry in this soil, the moisture is held with a force of 130 or more atmospheres. At II per cent above air-dry the holding power has fallen to 22.4 atmospheres.

c) At the wilting coefficient of the soil ( $\mathrm{I}_{3} .3$ per cent above air-dry in the Oswego silt loam subsoil) the "back pull" of the soil particles amounts to not more than that of a o. IM. $\mathrm{NaCl}$ solution, that is, not more than about 4 atmospheres. This is shown to hold true for a number of types of soil with widely varying wilting coefficients.

5. This water-holding power of soils at the wilting coefficient is less than the osmotic pressure of the root hairs of many kinds of plants, as shown by HANNIG and others.

6. The wilting of plants at the wilting coefficient of the soil cannot be due to lack of moisture in the soil, nor to lack of a gradient of forces tending to move water toward the plant.

7. The view is held, therefore, that the wilting at this critical soil moisture content must be due to the increasing slowness of water movement from soil particle to soil particle, and from these to the root hairs, the rate of movement falling below that necessary to maintain turgidity of the cells of the aerial parts, even under conditions of low transpiration. 
My thanks are due to Professor L. E. CALL, of the Kansas State Agricultural College, Manhattan, for sending me the subsoil of the Oswego silt loam used in these experiments, and to Dr. LYMAN J. BRIGGS and his assistants in the biophysical laboratory of the Bureau of Plant Industry for making determinations of the moisture equivalent of the local soils, hygroscopic determinations of the seeds in the vacuum driers, and for the various soil types which were so kindly sent to me. I desire also to express my appreciation of the generous way in which the Hull Botanical Laboratory has provided all needed facilities for the work, and especially my indebtedness and gratitude to Dr. WILLIAM CROCKER for much helpful advice and encouragement received during the progress of the work.

UNIVERSITY OF KANSAS

LAWRENCE, KaN.

\section{LITERATURE CITED}

I. Alwax, F. J., Studies on the relation of the nonavailable water of the soil to the hygroscopic coefficient. Neb. Agric. Exp. Sta. Research Bull. no. 3. 5-I22. I9I3.

2. Bancroft, Wilder D., The action of water vapor on gelatine. Jour. Phys. Chem. 16:395-406. I912.

3. Bogdanoff, S., Über das Verhalten der keimenden Samen zum Wasser im allgemeinen, und speziell zur Bodenfeuchtigkeit. Landw. Versuchs-Stat. 42:3II-366. I893.

4. BRown, A. J., On the existence of a semipermeable membrane enclosing the seeds of some of the Gramineae. Ann. Botany 21:79-87. 1907.

5. Brown, P. E., and Smith, R. E., Bacterial activities of frozen soils. Iowa Agric. Exp. Sta. Research Bull. no. 4. I9I2.

6. Briggs, L. J., and McLane, J. W., The moisture equivalents of soils. Bur. of Soils Bull. no. 45. I907.

7. Briggs, L. J., and Shantz, H. L., The wilting coefficient and its indirect determination. Вот. GAZ. 53:20-37. I9 2 .

8. - The wilting coefficient for different plants and its indirect determination. Bur. Plant Industry Bull. no. 230. Igr2.

9. Caldwell, J. S., The relation of environmental conditions to the phenomenon of permanent wilting in plants. Physiol. Res. I: I-56. I9I3.

io. Cameron, Frank K., The soil solution. igit.

ir. Carter, Williani T., Jr., and Simth, Howard C., Soil survey of Riley County, Kansas. 8th report, Field Operations of the Bureau of Soils, pp. 9I I-94I. I906. 
I2. Drabble, E., and Drabble, H., The relation between the osmotic strength of cell sap in plants and their physical environment. Biochem. Jour. 2:II7-I32. I907.

I3. Drabble, E., and Lake, H., The osmotic strength of cell sap in plants growing under different conditions. New Phytol. 4:189-I9I. I905.

I4. Fitting, H., Die Wasserversorgung und die Druckverhältnisse der Wüstenpflanzen. Zeitschr. Bot. 3:209-275. I9II.

I5. Hannig, E., Untersuchungen über die Verteilung des osmotischen Drucks in der Pflanze in Hinsicht auf die Wasserleitung. Ber. Deutsch. Bot. Gesells. 30:194-204. I912.

r6. Hilgard, E. W., Silt analyses of Mississippi soils and subsoils. Amer. Jour. Sci. 7:9-I7. I874.

17. - - The soil. Macmillan. I9II.

18. HILI, T. G., Osmotic properties of salt marsh plants. New Phytol. 7 : I33-I42, I908.

19. JUNGK, C. G., Über Temperaturerniedrigung bei der Absorption des Wassers durch feste porose Körper. Pogg. Ann. Physik u. Chemie r 25:292308. 1865 .

20. LAGERGReN, S., Über die beim Benetzen fein verteilter Körper auftretende Wärmetönung. Bihang till K. Sv. Vet. Akad. Handl. 24²: no. 5. pp. I4. I 898 ,

2I. Mitscherlich, E. A., Bodenkunde für Land- und Forstwirthe. Berlin. 1905.

22. Müntz, A., and Gaudechon, H., Les dégagements de chaleur qui se produisent au contact de la terre sèche et l'eau. Ann. Sci. Agron. $4^{2}: 393^{-}$ 443. 1909 .

23. NäGeli, CaRL von, Theorie der Gärung. I33-I55. München. I879.

24. Nernst, W., Theoretical chemistry, 3d ed. Macmillan. igr4.

25. Patten, Harrison E., Energy changes accompanying absorption. Trans. Amer. Electrochem. Soc. II:387-407. 1907.

26. Pounllet, C. S. M., Mémoire sur de nouveaux phénomènes de production de chaleur. Ann. de Chim. et de Phys. 20:I4I-I62. I822.

27. Rodewald, H., Úber die Quellung der Stärke. Landw. Versuchs-Stat. 45:20I-227. I895.

28. Rose, Gustav., Über die Fehler, welche in der Bestimmung des specifischen Gewichtes der Körper entstehen wenn man dieselben im Zustande der feinsten Vertheilung wägt. Pogg. Ann. Physik u. Chemie 73:I-I8. I848.

29. SAchs, J. von, Vorlesungen über Pflanzenphysiologie. 5th ed. Vol. I. p. 265. Leipzig. I 882 .

30. Schröder, H., Über die selektiv permeable Hülle des Weizenkornes. Flora I02:I86-208. I9II.

3I. SCHRÖDER, PAUl von, Über Erstarrungs- und Quellungserscheinungen von Gelatine. Zeitschr. Phys. Chem. 45:75-II7. I903. 
32. Shive, J. W., and Livingston, B. E., The relation of atmospheric evaporating power to soil moisture content at permanent wilting in plants. Plant World I7:8I-I2I. I9I4.

33. Shull, Charles A., Semipermeability of seed coats. Bot. Gaz. 56: i69I99. I9I3.

34. - Physiological isolation of types in the genus Xanthium. Bот, Gaz. 59:474-483. I9I5.

35. Walker, James, Introduction to physical chemistry. 7 th ed. Macmillan. I9I3.

36. Whitney, Milton, and Cameron, F. K., Investigations in soil fertility. Bureau of Soils Bull. no. 23. I904. 


LIBRARY OF CONGRESS

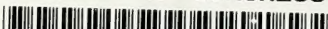

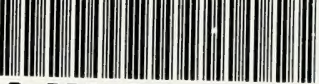

00027818560 